\title{
Biochemical Characteristics of Penicillium crustosum FP 11 Xylanase II and an Assessment of the Properties of Xylanases Produced by the Genus Penicillium
}

\author{
Jorge W. F. Bittencourt', Vanessa C. Arfelli ${ }^{1}$, Jaina C. Lunkes ${ }^{1}$, \\ Carla L. D. Torre ${ }^{1}$, Jose L. C. Silva ${ }^{1}$, Alexandre Maller ${ }^{1}$, \\ Rita de Cássia G. Simão ${ }^{1}$ and Marina K. Kadowaki ${ }^{1 *}$ \\ ${ }^{1}$ Centro de Ciências Médicas e Farmacêuticas, Universidade Estadual do Oeste do Paraná, \\ Rua: Universitária, 2069, CEP:85819-110, Cascavel, Paraná, Brazil.
}

Authors' contributions

This work was carried out in collaboration among all authors. Authors JWFB, VCA and JCL designed the study and wrote the first draft of the manuscript. Author CLDT wrote the protocol. Authors JLCS and AM managed the analyses of the study. Author RCGS managed the literature searches. All authors read and approved the final manuscript.

Article Information

DOI: $10.9734 / A R R B / 2020 / v 35 i 730248$ Editor(s):

(1) Dr. Viduranga Y. Waisundara, Australian College of Business Technology, Sri Lanka.

Reviewers:

(1) Abeer Abas Abd El Aty, National Research Centre, Egypt. (2) Virginia Vanzzini Zago, Dq Microbiology Laboratories Ltd, Mexico. Complete Peer review History: http://www.sdiarticle4.com/review-history/59171

Original Research Article

Received 08 May 2020

Accepted 14 July 2020

Published 30 July 2020

\begin{abstract}
Penicillium crustosum FP 11 produces two extracellular xylanase, which are designated xylanase I and II, and are induced by corn stover. In this work, xylanase II was purified 40-fold with a recovery yield of $9.2 \%$ using DEAE-Sephadex and Sephadex G-75 gel filtration, and the biochemical characteristics of the enzyme were compared with other xylanases produced by the genus Penicillium. Xylanase II exhibited a single band on SDS-PAGE, and had an apparent molecular mass of $28 \mathrm{kDa}$. The optimal temperature and $\mathrm{pH}$ of xylanase II activity were $50^{\circ} \mathrm{C}$ and 5.5 , respectively. Xylanase II had activities of 61,53 and $55 \%$ in the presence of $\mathrm{Mg}^{2+}$, DTT and $\beta-$ mercaptoethanol, respectively; however, the enzyme was strongly inhibited by $5 \mathrm{mM} \mathrm{Cu}^{2+}$, EDTA, and SDS. Hydrolysis of beechwood xylan released mainly xylose and short-chain xylo-
\end{abstract}


oligosaccharides as final products. Thus, an assessment of the enzymatic properties of xylanase II showed that its biochemical characteristics are best suited for the saccharification of lignocellulosic biomass into fermentable sugars.

Keywords: Penicillium crustosum FP 11; biochemical characterization; purification; xylooligosaccharides.

\section{INTRODUCTION}

Xylanases (E.C. 3.2.1.8) are enzymes that randomly cleave the $\beta-1,4$ linkages that connect xylose molecules of the xylan backbone [1,2], a component of the plant cell wall [3]. Xylanases have several biotechnological applications, which are determined by their biochemical characteristics. Active alkaline xylanases at elevated temperatures may be employed in the pulp and paper industry [4], while active acid xylanases at moderate temperatures can be used to clarify juices by reducing turbidity [5] via saccharification, converting lignocellulosic biomass into fermentable sugars for the production of ethanol [6] and baking by improving the characteristics of bread [7]. In addition, xylanases hydrolyze lignocellulosic biomass to produce xylo-oligosaccharides (XOS), which can be used as prebiotics and to stimulate bacterial growth beneficial to the human host [8]. These xylanases are produced by various microorganisms, such as filamentous fungi, bacteria, and yeast. Currently, the xylanases from microorganisms are some of the most industrially important enzymes produced, and the demand for fungal xylanases is even greater than for similar enzymes produced by other microorganisms, such as bacteria and yeast. This is due to the large capacity of fungi to secrete enzymes into the extracellular environment [9].

In this context, it is important to search for microorganisms capable of expressing high levels of these enzymes for the large-scale development of fermentation processes, to enhance xylanase purification strategies, and for the decrease costs $[10,11,12]$. Among the filamentous fungi, members of the genus Penicillium have been described as key xylanase producers [13,14]. However, there are few reports regarding enzyme production with the fungus Penicillium crustosum. In a previous study, two xylanolytic enzymes were induced in $P$. crustosum FP 11 with corn stover, xylanase I and II. Xylanase I has previously been purified and characterized [15]. Thus, in the present study, extracellular xylanase II produced from $P$. crustosum was purified and its biochemical characteristics were compared with other xylanases produced by the genus Penicillium.

\section{MATERIALS AND METHODS}

\subsection{Chemicals}

All the chemicals used were of reagent grade. The following substances were used: Potato Dextrose Agar (HiMedia Laboratories), salts used in the culture medium (Synth and Merck), dinitrosalicylic acid, beechwood xylan, bovine serum albumin, DEAE-Sephadex, Sephadex G75 , Coomassie Brilliant Blue R-250, (Sigma Aldrich, Brazil) Triton X-100, Congo red (Merck) TLC silica plate (Alufolien DC-Kieselgel 60, Merck®).

\subsection{Microorganism and Culture Conditions}

The fungus, $P$. crustosum, was previously isolated from the Atlantic forest biome of ParanáBrazil and taxonomically identified. Its sequence has been deposited in GenBank (access number: KM065878). The fungus was maintained on potato dextrose agar (PDA) medium at $4^{\circ} \mathrm{C}$. P. crustosum spores were used to inoculate modified Czapek liquid medium, which was supplemented with $2 \%(\mathrm{w} / \mathrm{v})$ corn stover as a carbon source, as described by Silva et al [16]. The fungus was cultivated under stationary conditions at $28^{\circ} \mathrm{C}$. After 6 days, cultures were filtered, and the enzymatic extract obtained was used to purify xylanase.

\subsection{Enzyme Assay and Protein Determination}

Xylanase activity was measured by determining reducing sugar content using dinitrosalicylic acid (DNS), as described by Miller [17]. Fifty microliters of the enzyme was incubated in $50 \mu \mathrm{L}$ beechwood xylan (1\%) in $50 \mathrm{mM}$ sodium acetate, $\mathrm{pH} 5.5$ for $10 \mathrm{~min}$ at $50^{\circ} \mathrm{C}$. Then, $100 \mu \mathrm{L}$ DNS reagent was added to the reaction mixture and it was boiled $5 \mathrm{~min}$. One unit of activity (U) was defined as the amount of enzyme needed to release $1 \mu \mathrm{moL}$ reducing sugars per minute 
using xylose as a standard. Specific activity was expressed in units $(U)$ per $\mathrm{mg}$ protein. Protein quantification was performed according to the Bradford [18] using bovine serum albumin (BSA) as a standard. Proteins that had been eluted from chromatographic columns were monitored by measuring absorbance at $280 \mathrm{~nm}$.

\subsection{Xylanase Purification}

The crude extract obtained from the $P$. crustosum corn stover culture was centrifuged for $10 \mathrm{~min}$ at $2,500 \mathrm{rpm}$ at $4^{\circ} \mathrm{C}$, and the supernatant was dialyzed for $18 \mathrm{~h}$. The enzymatic extract was equilibrated to a final concentration of $20 \mathrm{mM}$ in Tris- $\mathrm{HCl}$ buffer $(\mathrm{pH} \mathrm{7.5)}$ and was loaded on a DEAE-Sephadex ion-exchange chromatography column $(10 \times 2.0 \mathrm{~cm})$ as described by Dapper et al. [19]. Then, $2.5 \mathrm{~mL}$ fractions were collected at a flow rate of $1 \mathrm{~mL} \mathrm{~min}{ }^{-1}$, and resin-bound proteins were eluted using a $\mathrm{NaCl}$ gradient $(0.05$ to $1.0 \mathrm{M}$ ). Fractions exhibiting xylanase activity were pooled and dialyzed for $18 \mathrm{~h}$. The sample was then concentrated and $950 \mu \mathrm{L}$ was loaded onto a Sphadex G-75 gel filtration column and eluted with $20 \mathrm{mM}$ acetate buffer $(\mathrm{pH} \mathrm{5.5)}$ at a flow rate of $0.5 \mathrm{~mL} \mathrm{~min}{ }^{-1}$, and a pure xylanase sample was obtained.

\subsection{SDS-PAGE and Zymogram}

SDS-PAGE electrophoresis was performed according to methods described by Laemmli [20] on $10 \%$ acrylamide. After electrophoresis, the gel was cut into two parts, each containing one set of samples. The first gel was stained with Coomassie Brilliant Blue R-250 to assess protein homogeneity, and the other was used for zymogram analysis. The gel was incubated in $0.5 \%(\mathrm{v} / \mathrm{v})$ Triton $\mathrm{X}-100$ for $30 \mathrm{~min}$ at room temperature. After being washed with distilled water, the gel was incubated in $1 \%(\mathrm{w} / \mathrm{v})$ xylan (prepared in $50 \mathrm{mM}$ sodium acetate buffer, $\mathrm{pH}$ $5.5)$ at $50^{\circ} \mathrm{C}$ for $30 \mathrm{~min}$. Then, the gel was stained with $0.5 \%(\mathrm{w} / \mathrm{v})$ Congo red for $10 \mathrm{~min}$ at room temperature and distained with $1.0 \mathrm{M} \mathrm{NaCl}$ to reveal bands corresponding with enzymatic activity (light zone). The gel was kept in $1 \%$ acetic acid solution.

\subsection{Influence of Temperature and $\mathrm{pH}$ on Xylanase Activity}

The optimal $\mathrm{pH}$ for enzymatic activity was determined by performing an enzyme assay using $1 \%$ xylan beechwood for $10 \mathrm{~min}$ at $50^{\circ} \mathrm{C}$ using citrate-phosphate buffer in the $3.0-8.0 \mathrm{pH}$ range. Xylanase stability at a particular $\mathrm{pH}$ was measured using $\mathrm{pH} 4.5,5.5,6.5$, and 7.0 citratephosphate buffer for up to $48 \mathrm{~h}$, without the substrate. Aliquots were withdrawn at an interval of $0-48 \mathrm{~h}$ to measure residual activity.

The optimal temperature for enzymatic activity was determined by incubating the enzyme with xylan (in $50 \mathrm{mM}$ sodium acetate, $\mathrm{pH} 5.5$ ) for 10 min at varying temperatures of $35-75^{\circ} \mathrm{C}$. Thermal stability of xylanase was measured by incubating the enzyme at temperatures of $30^{\circ} \mathrm{C}$, $40^{\circ} \mathrm{C}, 50^{\circ} \mathrm{C}$, and $60^{\circ} \mathrm{C}$. Aliquots were withdrawn at $0-180$ minute intervals to determine residual activity.

\subsection{Determination of Kinetic Analysis}

The kinetic parameters $(\mathrm{Km}$ and $V \max )$ of $P$. crustosum xylanase II were determined using 1$24 \mathrm{mg} / \mathrm{mL}$ beechwood xylan. Enzymatic activity was measured using the standard dosage. $\mathrm{Km}$ and Vmax values were estimated via linear regression from double-reciprocal plots according to methods described by Lineweaver and Burk [21] using Origin 8.0 software.

\subsection{Analysis of Hydrolyzed Products}

End-products of xylanase hydrolysis were determined using thin layer chromatography (TLC) and high pressure liquid chromatography (HPLC). First, $500 \mu \mathrm{L}$ of the enzyme was mixed with $500 \mu \mathrm{L}$ xylan beechwood $(1 \%, \mathrm{w} / \mathrm{v})$ and incubated at $50^{\circ} \mathrm{C}$. Aliquots were withdrawn after 0, 30, 60, $120160 \mathrm{~min}$, or 12 and $24 \mathrm{~h}$ (for HPLC analysis), and subsequently boiled at $100^{\circ} \mathrm{C}$ for 5 min. Mixtures not containing enzyme were used as negative controls. TLC samples were spotted on silica plates and butanol:pyridine:water (7:3:1 $\mathrm{v} / \mathrm{v}$ ) was used as a solvent system according to Correa et al. [22] Products of hydrolysis were detected by spraying with $0.1 \%(\mathrm{w} / \mathrm{v})$ orcinol in sulfuric acid:methanol (1: $9 \mathrm{v} / \mathrm{v})$, followed by heating at $100^{\circ} \mathrm{C}$ for a few min. For HPLC analysis, aliquots of $20 \mathrm{uL}$ were quantified using HPLC (Shimadzu model RID 20-A) using a refractive index detector and a $200 \times 10 \mathrm{~mm}$ RSO-Oligosaccharide $\mathrm{Ag}^{+} \quad(4) \%$ column maintained at $75^{\circ} \mathrm{C}$ with Mili-Q water as a mobile phase $(0.6 \mathrm{~mL} / \mathrm{min}$ flow rate). The standards used were xylose (X1), xylobiose (X2), xylotriose (X3) and xylotetraose (X4).

\subsection{Effect of Metal lons and Additives on Enzyme Activity}

Regarding the effect of various compounds $\left(\mathrm{Co}^{2+}, \mathrm{K}^{+}, \mathrm{Na}^{+}, \mathrm{Sn}^{2+}, \mathrm{Ba}^{2+}, \mathrm{Ca}^{2+}, \mathrm{Hg}^{2+}, \mathrm{Fe}^{2+}\right.$, 
$\mathrm{Mg}^{2+}, \mathrm{Cu}^{2+}, \mathrm{Mn}^{2+}, \mathrm{Zn}^{2+}$, EDTA, SDS, Triton $\mathrm{X}-$ 100, DTT, $\beta$-mercaptoethanol, ethanol, and acetone) on xylanase activity, the final concentration of compounds within the reaction mixture were $1 \mathrm{mM}$ and $5 \mathrm{mM}$ (metal ions and reducing agents) and $1 \%$ and $5 \%$ (detergents and organic solvents). The residual activity was determined by standard enzymatic assay.

\section{RESULTS AND DISCUSSION}

\subsection{Xylanase Purification}

$P$. crustosum expressed two xylanases, named xylanase I (not bound to DEAE) and xylanase II (bound to DEAE). After the sample was eluted from the DEAE-Sephadex ion-exchange column, Xylanase II was eluted from the column using a 0.3-0.48 M NaCl gradient. Xylanase II was purified 40 -fold with a recovery yield of $9.2 \%$ after Sephadex G-75 gel filtration, as shown in Table 1. Enzyme purity was confirmed via zymogram and the molecular mass of the enzyme was estimated using SDS-PAGE, which revealed a single band with an apparent molecular mass molecular weight of $28 \mathrm{kDa}$ that was greater than xylanase I (23.4 kDa) (Fig. 1). The molecular mass of this xylanase was different than those of other xylanases produced by Penicillium strains (Table 2), but was similar to the $30 \mathrm{kDa}$ weight previously determined for $P$. funiculosum PfXynC xylanase [23] and PoXyn2 of $P$. occitanis Pol6 [24].

\subsection{Effect of Temperature on Xylanase Activity and Stability}

The optimal temperature determined for $P$. crustosum xylanase II was the same obtained for xylanase I of $50^{\circ} \mathrm{C}$ (Fig. 2A), which was the temperature previously shown to be optimal for $P$. canescens xylanases [25] and $P$. rolfsii c32(1) IBRL [26]. However, optimal temperatures of $40^{\circ} \mathrm{C}$ and $80^{\circ} \mathrm{C}$ have also found for some fungal xylanases of $P$. occitanis Pol6 [24] and $P$. funiculosum [27], respectively. A great variability with regard to optimal temperature for enzymatic activity exists among the Penicillium mesophilic fungal xylanases. In fact many are most active at elevated temperatures, such as $75^{\circ} \mathrm{C}$ for $P$. pinophlum $\mathrm{C} 1$ xylanase [28] and $80^{\circ} \mathrm{C}$ for $P$. funiculosum XynD [27].

Table 1. Summary of steps used to purify xylanase II from $P$. crustosum grown on corn stover

\begin{tabular}{llllll}
\hline steps & $\begin{array}{l}\text { Total } \\
\text { activity }\end{array}$ & $\begin{array}{l}\text { Total proteins } \\
\text { (mg) }\end{array}$ & $\begin{array}{l}\text { Specific activity } \\
{\left.\mathbf{( U ~} \mathbf{~ m g}^{-1}\right)}^{-1}\end{array}$ & $\begin{array}{l}\text { Yield (\%) } \\
\text { Purification } \\
\text { factor (fold) }\end{array}$ \\
\hline Crude supernatant & $3,572.0$ & 692 & 5.16 & 100 & 1 \\
DEAE-Sephadex & $1,047.2$ & 31.45 & 33.29 & 29.3 & 6.45 \\
Gel filtration & 328.65 & 1.59 & 206.70 & 9.2 & 40.06 \\
(Sephadex-G75) & & & & & \\
\hline
\end{tabular}

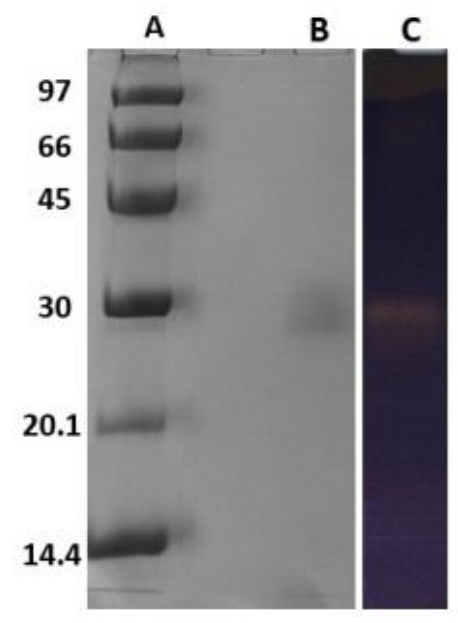

Fig. 1. SDS-PAGE and zymogram of xylanase II purified from $P$. crustosum

Lane A: low molecular weight marker: phosphorylase b (97 kDa); albumin (66 kDa); ovalbumin (45 kDa); carbonic anhydrase (30 kDa); trypsin inhibitor (20.1 kDa); and $\alpha$-lactalbumin (14.4 kDa). Lane B: xylanase after Sephadex G-75. Lane C: xylanase II activity zymogram 

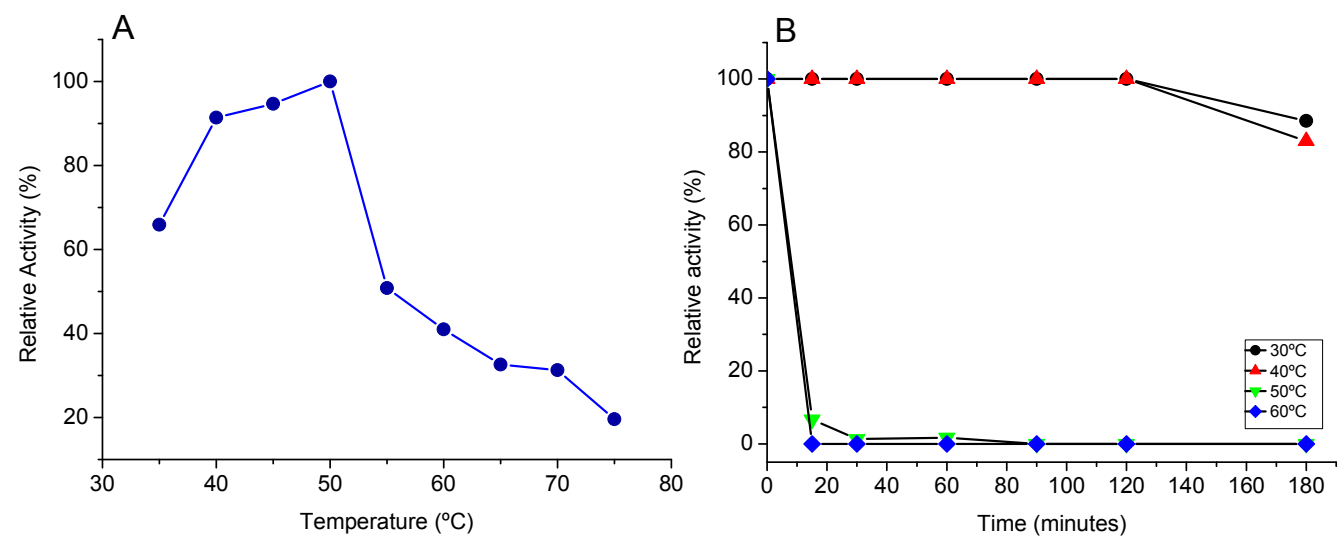

Fig. 2. Optimum temperature (A) and thermal stability (B) for purified xylanase II activity

The optimal temperatures were determined at temperatures between $35^{\circ} \mathrm{C}$ and $75^{\circ} \mathrm{C}$, using $1 \%$ beechwood xylan in a $50 \mathrm{mM}$ sodium acetate buffer ( $\mathrm{pH}$ 5.5) as a substrate. Thermal stability was determined by measuring residual enzyme activity after incubation at $30^{\circ} \mathrm{C}, 40^{\circ} \mathrm{C}, 50^{\circ} \mathrm{C}$, and $60^{\circ} \mathrm{C}$ for up to $180 \mathrm{~min}$

Xylanase II exhibited $100 \%$ thermal stability at $35-40^{\circ} \mathrm{C}$ temperatures, and its activity declined after a $2 \mathrm{~h}$ incubation period (Fig. 2B). At temperatures of $50-60^{\circ} \mathrm{C}$, the enzymatic activity decreased and became inactivated after $15 \mathrm{~min}$. Thus, xylanase II has the potential to be used for the saccharification of lignocellulosic materials and XOS production, which demand mild temperatures.

\subsection{Influence of pH on Xylanase Activity and Stability}

$P$. crustosum xylanase II exhibited maximal activity at $\mathrm{pH} 5.5$ (Fig. 3A) slightly higher than that of xylanase I (Table 2) [15]. Similar $\mathrm{pH}$ values were also obtained from xylanases of $P$. chrysogenum FS010 [29]. However, most Penicillium xylanases reported (Table 2) have maximum enzymatic activity at acidic $\mathrm{pH}$, ranging from $\mathrm{pH} 2.0$ for $P$. occitanis [30] to $\mathrm{pH} 6.0$ for the xylanases produced by $P$. janczewskii [31], $P$. oxalicum GZ-2 [6] and XynB of $P$. citrinum GERM P-15944 [32]. However, others functioned optimally at neutral and alkaline-range $\mathrm{pH}$. For instance, xylanase A produced by $P$. purpurogenum [33] functions optimally at $\mathrm{pH} 7.0$, Penicillium sp. SS1 [34] at $\mathrm{pH} 8.0$, and $P$. citrinum at $\mathrm{pH} 8.5$ [35].

Xylanase II exhibited $\mathrm{pH}$ stability in the range of 5.5-7.0, the enzyme retained more than $80 \%$ of its activity for up to $48 \mathrm{~h}$. However, it was most highly stable at $\mathrm{pH} 7.0$, and $90 \%$ of its enzymatic activity was retained after $48 \mathrm{~h}$ (Fig. 3B).
According to Törrönen and Rouvinen [36], xylanases with alkaline $\mathrm{pH}$ activity may be active at a broad $\mathrm{pH}$ range of 4.0-8.0, while xylanases that function optimally at acidic $\mathrm{pH}$ have a narrower range of 3.0-6.0.

\subsection{Kinetic Parameters}

The apparent $\mathrm{Km}$ and Vmax values determined here, using beechwood xylan as substrate, were $1.1 \mathrm{mg} / \mathrm{mL}$ and $1,064 \mathrm{U} / \mathrm{mg}$, respectively. A Km of $1.0 \mathrm{mg}$ with beechwood xylan was also obtained for xylanase Xyn10B produced by $P$. oxalicum [6]. A comparison with the $\mathrm{Km}$ value obtained for $P$. crustosum xylanase II shows that this enzyme has a relatively greater affinity for beechwood xylan. However, xylanases with even greater $\mathrm{Km}$ have previously been identified, including P. oxalicum GZ-2 Xyn 10B and $P$. oxalicum B3-11(2), which produced $\mathrm{Km}$ values of $3.0 \mathrm{mg} / \mathrm{mL}$ [6] and $4.6 \mathrm{mg} / \mathrm{mL}$ [37], respectively.

\subsection{Analysis of Hydrolyzed Products}

The means by which purified xylanase hydrolyzed beechwood xylan was assessed using TLC (Fig. 4A). These analyses showed that xylanase II hydrolyzes $\beta-1,4$ linkages of both inner and outer ends of the xylan substrate, and mainly releases $X 1, X 2$ and $X 3$ as products. This is similar to reactions of XynA and XynB from $P$. citrinum FERM P-15944 [32,38] and the xylanase from Penicillium sp. SS1 [34]. Some enzymes produce exclusively $\mathrm{X} 2$ and $\mathrm{X} 3$ products, such as 
$P$. crustosum FP 11 xylanase I [15], $P$. canascens xylanase [39], and a large number of other Penicillium xylanases released X1, X2, X3, $X 4, X 5$, and xylooligosaccharides (Table 2). Using HPLC, xylose (2.76 and $3.14 \mathrm{mg} / \mathrm{mL})$ and xylobiose $(5.61$ and $5.96 \mathrm{mg} / \mathrm{mL})$ were obtained after 12 and $24 \mathrm{~h}$, respectively (Fig. 4B). However, the amount of xylotriose $(0.95 \mathrm{mg} / \mathrm{mL})$ and xylotetraose $(0.03 \mathrm{mg} / \mathrm{mL})$ did not differ after
12 and $24 \mathrm{~h}$ (Fig. 3B). Similar results were obtained with XynA and XynB from $P$. citrinum FERM P-15944 [32,38] and xylanase from Penicillium sp. SS1 [34]. The production of short-chain xylo-oligosaccharides and xylose by $P$. crustosum xylanase II reveals that the enzyme is an endo and exo-xylanase, and could promote the saccharification of lignocellulosic biomass into fermentable sugars.
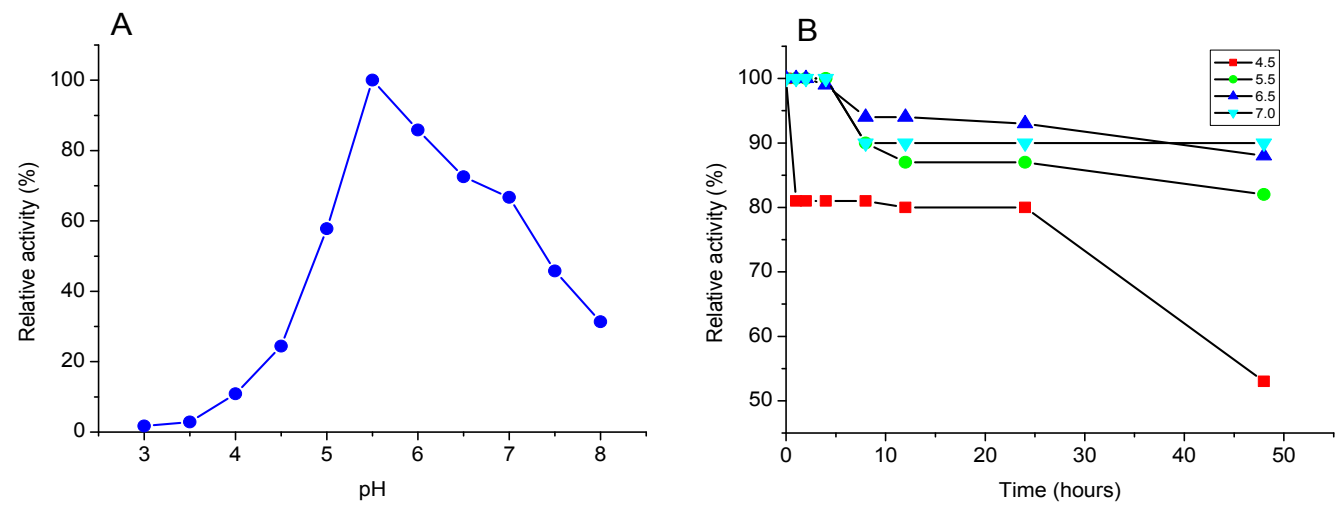

Fig. 3. Optimal pH (A) and pH stability (B) of $P$. crustosum xylanase II

Optimal $\mathrm{pH}$ was assessed by incubating the enzyme in $\mathrm{pH} 3.0-8.0$ citrate-phosphate buffer with $1 \%$ xylan beechwood substrate. $\mathrm{pH}$ stability was determined by measuring residual enzymatic activity after incubation in citrate-phosphate buffer at $\mathrm{pH} 4.5,5.5,6.5$, and 7.0 for up to $48 \mathrm{~h}$

A

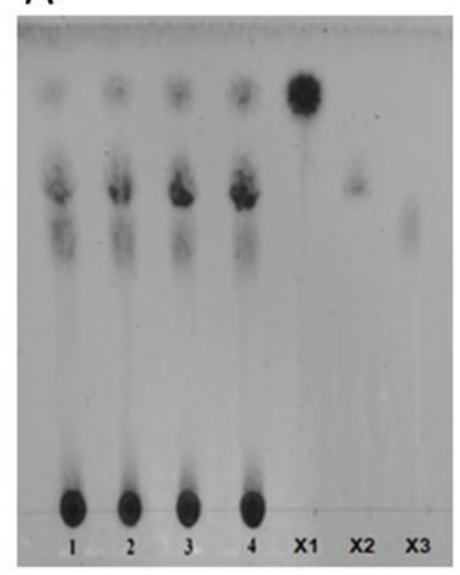

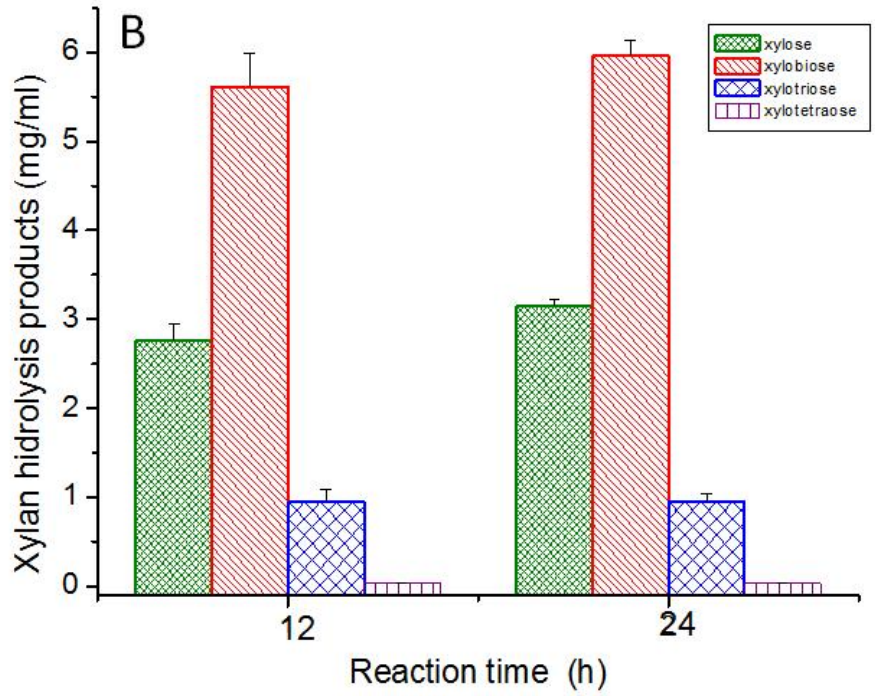

FIG. 4. Analysis of the products of $P$. crustosum xylanase ii hydrolysis using thin layer chromatography (a)

The enzymatic reaction was stopped after 30, 60, 120 and $160 \mathrm{~min}$, as shown in lanes 1, 2, 3 and 4, respectively. The standards included xylose $(x 1)$, xylobiose $(x 2)$, xylotriose $(x 3)$ and xylotetraose $(x 4)$. Hplc analysis of products of beechwood xylan hydrolysis after 12 and $24 h$ (b). 
Bittencourt et al.; ARRB, 35(7): 64-75, 2020; Article no.ARRB.59171

Table 2. Properties of xylanases produced by fungi of the genus penicillium

\begin{tabular}{|c|c|c|c|c|c|c|c|c|}
\hline Penicillium Strain & $\begin{array}{l}\text { Enzyme } \\
\text { name }\end{array}$ & $\begin{array}{l}\text { Molecular } \\
\text { mass (kDa) }\end{array}$ & Optimum pH & pH stability & $\begin{array}{l}\text { Optimum } \\
\text { Temperature }\left({ }^{\circ} \mathrm{C}\right)\end{array}$ & $\begin{array}{l}\text { Thermal } \\
\text { stability }\end{array}$ & $\begin{array}{l}\text { Xylan hydrolysis } \\
\text { products }\end{array}$ & References \\
\hline $\begin{array}{l}\text { Penicillium } \\
\text { crustosum FP } 11\end{array}$ & Xylanase II & 28 & 5.5 & $5.5-7.0$ & 50 & $30-40$ & $\mathrm{X} 1, \mathrm{X} 2, \mathrm{X} 3$ & This work \\
\hline $\begin{array}{l}\text { Penicillium } \\
\text { crustosum FP } 11\end{array}$ & Xylanase I & 23.4 & 5.0 & $4.0-7.0$ & 50 & $40-50$ & $\mathrm{X} 2, \mathrm{X} 3$ & [15] \\
\hline $\begin{array}{l}\text { Penicillium oxalicum } \\
\text { GZ-2 }\end{array}$ & XYN11A & 21.3 & 3.0 & $3.0-5.0$ & 50 & $50-60$ & $X 4, X 5, X 6$ & [42] \\
\hline $\begin{array}{l}\text { Penicillium } \\
\text { janczewskii }\end{array}$ & Xyl 1 & 30.4 & 6.0 & $2.5-10.0$ & 65 & $50-65$ & $\mathrm{X} 3, \mathrm{X} 4, \mathrm{XOS}$ & [31] \\
\hline $\begin{array}{l}\text { Penicillium } \\
\text { pinophilum C1 }\end{array}$ & XYN10C1 & 40 & $4.0-5.5$ & $3.0-6.5$ & 75 & $70-80$ & $\mathrm{X} 1$ and $\mathrm{X} 3$ & [28] \\
\hline $\begin{array}{l}\text { Penicillium occitanis } \\
\text { Pol6 }\end{array}$ & PoXyn3 & 20 & 4.0 & $2.0-10.0$ & 40 & $30-50$ & NR & [23] \\
\hline $\begin{array}{l}\text { Penicillium } \\
\text { funiculosum }\end{array}$ & PfXynC & 30 & 3.0 & $2.0-10.0$ & 45 & $30-50$ & NR & [23] \\
\hline $\begin{array}{l}\text { Penicillium oxalicum } \\
\text { GZ-2 }\end{array}$ & Xyn10A & 36 & 6.0 & $5.0-7.0$ & 40 & $40-45$ & $X 2, X 3, X 4$ & [6] \\
\hline $\begin{array}{l}\text { Penicillium oxalicum } \\
\text { GZ-2 }\end{array}$ & Xyn10B & 43 & 6.0 & $5.0-7.0$ & 70 & $50-70$ & $X 2, X 3, X 4$ & {$[6]$} \\
\hline $\begin{array}{l}\text { Penicillium oxalicum } \\
\text { GZ-2 }\end{array}$ & Xyn11A & 23 & 4.0 & $4.0-5.0$ & 50 & $40-45$ & $\mathrm{X} 2, \mathrm{X} 3, \mathrm{X} 4, \mathrm{X} 5$ & [6] \\
\hline $\begin{array}{l}\text { Penicillium oxalicum } \\
\text { GZ-2 }\end{array}$ & Xyn11B & 32 & 5.0 & $4.0-5.0$ & 50 & $40-45$ & $\mathrm{X} 2, \mathrm{X} 3, \mathrm{X} 4, \mathrm{X} 5$ & [6] \\
\hline $\begin{array}{l}\text { Penicillium } \\
\text { ramulosum N1 }\end{array}$ & xylanase & 25 & 3.0 & NR & 55 & NR & NR & [44] \\
\hline $\begin{array}{l}\text { Penicillium } \\
\text { canescens }\end{array}$ & XylE & 40 & $5.5-6.0$ & $4.0-8.0$ & 70 & $65-75$ & $\mathrm{X} 2, \mathrm{X} 3$ & [39] \\
\hline Penicillium citrinum & xylanase & 25 & 8.5 & $4.0-10.0$ & 50 & $30-50$ & NR & [35] \\
\hline Penicillium sp. SS1 & xylanase & NR & 8.0 & $6.0-10.0$ & 50 & $50-60$ & $\mathrm{x} 1, \mathrm{x} 2, \mathrm{x} 3, \mathrm{xOS}$ & [34] \\
\hline $\begin{array}{l}\text { Penicillium occitanis } \\
\text { Pol6 }\end{array}$ & PoXyn2 & 30 & 3.0 & $2.0-9.0$ & 50 & $30-50$ & NR & [24] \\
\hline Penicillium sp. F63 & Xyn11F63 & 21 & 4.5 & $4.5-9.0$ & 40 & $40-45$ & $\mathrm{X} 1, \mathrm{X} 2, \mathrm{X} 3, \mathrm{X} 4$ & [45] \\
\hline
\end{tabular}


Bittencourt et al.; ARRB, 35(7): 64-75, 2020; Article no.ARRB.59171

\begin{tabular}{|c|c|c|c|c|c|c|c|c|}
\hline Penicillium Strain & $\begin{array}{l}\text { Enzyme } \\
\text { name }\end{array}$ & $\begin{array}{l}\text { Molecular } \\
\text { mass (kDa) }\end{array}$ & Optimum pH & pH stability & $\begin{array}{l}\text { Optimum } \\
\text { Temperature }\left({ }^{\circ} \mathrm{C}\right)\end{array}$ & $\begin{array}{l}\text { Thermal } \\
\text { stability }\end{array}$ & $\begin{array}{l}\text { Xylan hydrolysis } \\
\text { products }\end{array}$ & References \\
\hline $\begin{array}{l}\text { CGMCC } 1669 \\
\text { Penicillium } \\
\text { funiculosum }\end{array}$ & XynD & 46 & $4.0-5.5$ & $4.0-5.5$ & 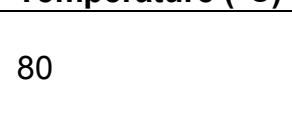 & $70-80$ & $\mathrm{X} 2, \mathrm{X} 3, \mathrm{X} 4$ & [29] \\
\hline Penicillium occitanis & PoXyn2 & NR & $2.0-4.0$ & NR & 65 & $50-65$ & NR & [30] \\
\hline $\begin{array}{l}\text { Penicillium oxalicum } \\
\text { B3-11(2) }\end{array}$ & PoxynA & 32 & 5.0 & $2.0-7.0$ & 50 & $30-50$ & $X 2, x 3, \times 5$ & [37] \\
\hline $\begin{array}{l}\text { Penicillium } \\
\text { chrysogenum } \\
\text { FS010 }\end{array}$ & Xyl & 38 & 5.5 & $4.5-8.0$ & 25 & $25-35$ & NR & [29] \\
\hline $\begin{array}{l}\text { Penicillium } \\
\text { purpurogenum }\end{array}$ & Xylanase A & 33 & 7.0 & $6.0-7.5$ & 60 & NR & NR & [33] \\
\hline $\begin{array}{l}\text { Penicillium } \\
\text { purpurogenum }\end{array}$ & Xylanase B & 23 & 3.5 & $6.0-7.5$ & 50 & NR & NR & [33] \\
\hline $\begin{array}{l}\text { Penicillium } \\
\text { sclerotiorum }\end{array}$ & Xylanase 1 & 23.9 & 2.5 & $1.6-3.0$ & 50 & $40-50$ & $\mathrm{x} 2, \mathrm{xOS}$ & [43] \\
\hline $\begin{array}{l}\text { Penicillium } \\
\text { sclerotiorum }\end{array}$ & Xylanase 2 & 33.1 & 4.5 & $3.0-7.0$ & 55 & $45-55$ & $\mathrm{x} 3, \mathrm{xOS}$ & [43] \\
\hline $\begin{array}{l}\text { Penicillium citrinum } \\
\text { FERM P-15944 }\end{array}$ & XynA & 20 & 5.0 & $2.0-10.0$ & 55 & NR & $\mathrm{X} 1, \mathrm{X} 2, \mathrm{X} 3, \mathrm{X} 4$ & [32] \\
\hline $\begin{array}{l}\text { Penicillium citrinum } \\
\text { FERM P-15944 }\end{array}$ & $\begin{array}{l}\text { XynB } \\
\text { (Endo-1,4-b- } \\
\text { xylanase) }\end{array}$ & 31.6 & 6.0 & $3.0-10.0$ & 50 & NR & $\mathrm{X} 1, \mathrm{X} 2, \mathrm{X} 3, \mathrm{xOS}$ & [38] \\
\hline
\end{tabular}




\subsection{Effect of Potential Inhibitors and Activators on Xylanase II Activity}

The effects of potential inhibitors and activators on purified xylanase II from $P$. crustosum is shown in Table 3. Xylanase II activity was stimulated $61.8,53.6$ and $55.7 \%$ in the presence of $5 \mathrm{mM} \mathrm{Mg}{ }^{2+}$, DTT and $\beta$-mercaptoethanol, respectively (Table 3 ). Querido et al. [40] also reported $P$. expansum xylanase activation by $\mathrm{Mg}^{+2}$. Enzymatic activation by thiol groupcontaining compounds, such as DTT and $\beta$ mercaptoethanol confirms the presence of a reduced thiol group of cysteine residue in this enzyme [41]. However, some compounds inhibited the enzymatic activity of $P$. crustosum xylanase, especially $\mathrm{Hg}^{2+}$ and $\mathrm{Cu}^{2+}$. Inhibition of xylanases by $\mathrm{Hg}^{2+}$ has been described by Liao et al. [42] in a xylanase from Penicillium oxalicum as well as $P$. sclerotiorum xylanase [43] Similarly, $\mathrm{Cu}^{2+}$ ions have widely been reported inhibitors of xylanases [28].

\section{Table 3. Effect of potential inhibitors and activators on $P$. crustosum xylanase II activity}

\begin{tabular}{|c|c|c|}
\hline \multirow[t]{2}{*}{ Compounds } & \multicolumn{2}{|c|}{ Residual activity $^{\mathrm{a}}(\%)$} \\
\hline & $1 \mathrm{mM}$ & $5 \mathrm{mM}$ \\
\hline Control & 100 & 100 \\
\hline $\mathrm{CoCl}_{2}$ & $109.3 \pm 0.02$ & $100.1 \pm 0.02$ \\
\hline $\mathrm{KCl}$ & $89.9 \pm 0.02$ & $77.1 \pm 0.04$ \\
\hline $\mathrm{NaCl}$ & $93.1 \pm 0.02$ & $68.4 \pm 0.06$ \\
\hline $\mathrm{SnCl}_{2}$ & $52.6 \pm 0.05$ & $19.0 \pm 0.01$ \\
\hline $\mathrm{BaCl}_{2}$ & $81.9 \pm 0.06$ & $71.4 \pm 0.01$ \\
\hline $\mathrm{CaCl}_{2}$ & $103.7 \pm 0.01$ & $120.6 \pm 0.01$ \\
\hline $\mathrm{HgCl}_{2}$ & $8.9 \pm 0.01$ & 0 \\
\hline $\mathrm{FeCl}_{2}$ & $81.5 \pm 0.04$ & $61.5 \pm 0.02$ \\
\hline $\mathrm{MgCl}_{2}$ & $100.3 \pm 0.02$ & $161.8 \pm 0.03$ \\
\hline $\mathrm{CuSO}_{4}$ & $43.4 \pm 0.02$ & $5.2 \pm 0$ \\
\hline $\mathrm{MnCl}_{2}$ & $108.2 \pm 0.02$ & $108.5 \pm 0.04$ \\
\hline $\mathrm{ZnSO}_{4}$ & $82.2 \pm 0.02$ & $80.7 \pm 0.01$ \\
\hline EDTA & $83.9 \pm 0.40$ & 0 \\
\hline ethanol & $70.5 \pm 0.02$ & $37.0 \pm 0.01$ \\
\hline Acetone & $86.7 \pm 0.01$ & $41.0 \pm 0.02$ \\
\hline SDS & $20.4 \pm 0.01$ & $16.7 \pm 0.01$ \\
\hline Triton X100 & $88.2 \pm 0.01$ & $58.9 \pm 0.03$ \\
\hline $\begin{array}{l}\beta- \\
\text { mercaptoethanol }\end{array}$ & $167.0 \pm 0.04$ & $155.7 \pm 0.03$ \\
\hline DTT & $141.8 \pm 0.05$ & $153.6 \pm 0.01$ \\
\hline
\end{tabular}

\section{CONCLUSION}

P. crustosum xylanase II exhibited biochemical properties different from xylanase I, but similar to many Penicillium xylanases. The enzyme was optimally active at acidic $\mathrm{pH}$ and was stable throughout an acidic to neutral $\mathrm{pH}$ range. The thermal stability of xylanase II was optimal at mild temperatures. An assessment of hydrolyzed products of the enzyme revealed that it exhibited both endo and exo-xylanase activity. However, an increased proportion of short-chain xylooligosaccharides and xylose were produced. Thus, an assessment of the enzymatic properties of xylanase II showed that its biochemical characteristics are best suited for the saccharification of lignocellulosic biomass into fermentable sugars for the production of bioethanol.

\section{ACKNOWLEDGEMENTS}

Jorge W. F. Bittencourt and Carla L. D. Torre were fellows of CAPES, the Coordination of Improvement of Higher Education Personnel. Vanessa C. Arfelli and Jaina C. Lunkes were fellows of Fundação Araucária-Brazil.

\section{COMPETING INTERESTS}

Authors have declared that no competing interests exist.

\section{REFERENCES}

1. Walia A, Guleria S, Mehta P, Chauhan A, Parkash J. Microbial xylanases and their industrial application in pulp and paper biobleaching: a review. 3 Biotech. 2017;7: 1-12.

Available:https://doi.org/10.1007/s13205016-0584-6

2. Subramaniyan S, Prema P. Biotechnology of microbial xylanases: enzymology, molecular biology, and application. Crit Rev Biotechnol. 2002;22:33-64.

3. $\mathrm{Hu} \mathrm{H}$, Chen K, Li L, Long L, Ding $\mathrm{S}$. Characterization of the Wild-Type and Truncated Forms of a Neutral GH10 Xylanase from Coprinus cinereus: Roles of C-Terminal Basic Amino Acid-Rich Extension in Its SDS Resistance, Thermostability, and Activity. J Microbiol Biotechnol. 2017;27:775-784.

Available:https://doi.org/10.4014/jmb.1609. 09011

4. Bajpai P. Application of Enzymes in the Pulp and Paper Industry. Biotechnol Prog. 1999;15:147-157.

5. Shahrestani H, Taheri-Kafrani A, Soozanipour A, Tavakoli O. Enzymatic clarificationof fruit juices using xylanase 
immobilized on 1,3,5-triazine-functionalized silica-encapsulated magnetic nanoparticles. Biochem Eng J. 2016;109: 51-58.

6. Liao H, Zheng $\mathrm{H}$, Li S, Wei Z, Mei X, Ma H, Shen $Q, X u Y$. Functional diversity and properties of multiple xylanases from Penicillium oxalicum GZ-2. Sci Rep. 2015; 5:12631.

Available:https://doi.org/10.1038/srep1263 1

7. Butt MS, Tahir-Nadeem M, Ahmad Z, Sultan MT. Xylanases and their applications in baking industry. Food Technol Biotechnol. 2008;46:22-31.

8. Chapla D, Pandit P, Shah A. Production of xilooligosaccharides from corncob xylan by fungal xylanase and their utilization by probiotics. Bioresour Technol. 2012;15: 215-221.

9. Menezes BS, Rossi DM, Ayub MAZ. Screening of filamentous fungi to produce xylanase and xylooligosaccharides in submerged and solid-state cultivations on rice husk, soybean hull, and spent malt as substrates. World J Microbiol Biotechnol. 2017;33:58.

Available:https://doi.org/10.1007/s11274017-2226-5

10. Araújo R, Casal M, Cavaco-Paulo A. Application of enzymes for textile fibres processing. Biocatal Biotransformation. 2008;26:332-349.

DOI: $10.1080 / 10242420802390457$

11. Gírio FM, Fonseca $C$, Carvalheiro $F$, et al. Hemicelluloses for fuel ethanol: A review. Bioresour Technol. 2010;101:4775-4800. DOI: 10.1016/j.biortech.2010.01.088

12. Torre CLD, Kadowaki MK. Thermostable xylanase from thermophilic fungi: Biochemical properties and industrial applications. African J Microbiol Res. 2017; 11:28-37.

Available:https://doi.org/10.5897/AJMR201 6.8361

13. Reis L, Fontana RC, Delabona PS, Lima DJS, Camassola M, Pradella JGC, Dillon AJP. Increased production of cellulases and xylanases by Penicillium echinulatum S1M29 in batch and fed-batch culture. Bioresour Technol 2013;146:597603.

Available:https://doi.org/10.1016/j.biortech. 2013.07.124

14. Mushimiyimana I, Tallapragada P. Research Journal of Pharmaceutical, Biological and Chemical Sciences
Statistical Optimization of Cellulase and Xylanase Enzyme Production by Penicillium Crustosum Using Sugar Beet Peel Substrate by Response Surface. Res J Phermaceutical, Biol Chem Sci. 2015;6: 1144-1151.

15. Lunkes JC, Arfelli VC, Bittencourt JWF, Menolli RA, Maller A, da Conceição Silva JL, Simão RCG, Kadowaki MK. Purification of a xylanase from Penicillium crustosum and its potential use in clarifying fruit juice. E-book: Análise Crítica das Ciências Biológicas e da Natureza 3, Atena Editora, Ponta Grossa- PR. 2019;3. DOI:10.22533/at.ed.59019270510

16. Silva NFDS, Simões MR, Knob A, Moraes SS, Henn C, Conceição Silva JL, Simão RDCG, Maller A, Kadowaki MK. Improvement in the bleaching of kraft pulp with xylanase from Penicillium crustosum FP 11 isolated from the Atlantic forest. Biocatal Biotransformation. 2016;34:119127.

Available:https://doi.org/10.1080/10242422 .2016.1212849

17. Miller GL. Use of Dinitrosalicylic Acid Reagent for Determination of Reducing Sugar. Anal Chem. 1959;31:426-428.

Available:https://doi.org/10.1021/ac60147a 030

18. Bradford MM. A rapid and sensitive method for the quantitation of microgram quantities of protein utilizing the principle of protein-dye binding. Anal Biochem. 1976; 72:248-254.

Available:https://doi.org/10.1016/00032697(76)90527-3

19. Dapper TB, Arfelli V, Henn C, Simões MR, dos Santos MF, Torre CLD, et al. Fructofuranosidase production by Aspergillus versicolor isolated from Atlantic forest and grown on apple pomace. Afr. J. Microbiol. Res. 2016;10:938-948.

DOI: 10.5897/ajmr2016.8038

20. Laemmli UK. Cleavage of Structural Proteins during the Assembly of the Head of Bacteriophage T4. Nature. 1970;227: 680-685.

Available:https://doi.org/10.1038/227680a0

21. Lineweaver H, Burk D. The Determination of Enzyme Dissociation Constants. J Am Chem Soc. 1934;56:658-666.

DOI: 10.1021/ja01318a036

22. Corrêa JM, Christi D, Della Torre CL, Henn C, Da Conceição-Silva JL, Kadowaki MK, Simão RCG High levelsof $\beta$-xylosidase in Thermomyces lanuginosus: 
potential use for saccharification. Braz J Microbiol. 2016;47:680-690

23. Driss $D$, Berrin JG, Juge $\mathrm{N}$, et al. Functional characterization of Penicillium occitanis Pol6 and Penicillium funiculosum GH11 xylanases. Protein Expr Purif. 2013; 90:195-201.

DOI: 10.1016/j.pep.2013.06.007

24. Driss D, Bhiri F, Ghorbel R, Chaabouni SE. Cloning and constitutive expression of Histagged xylanase GH 11 from Penicillium occitanis Pol6 in Pichia pastoris X33: Purification and characterization. Protein Expr Purif. 2012;83:8-14.

DOI: 10.1016/j.pep.2012.02.012

25. Serebryanyi VA, Vavilova EA, Chulkin AM, Vinetskii YP. Cloning of Penicillium canescens Endo-1,4- $\beta$-xylanase Gene and Construction of Multicopy Strains. Appl Biochem Microbiol. 2002;38:420-426.

Available:https://doi.org/10.1023/A:101990 8232700

26. Lee KC, Arai T, Ibrahim D, Prawitwong $P$, Lan D, Murata Y, Mori Y, Kosugi A. Purification and characterization of a xylanase from the newly isolated Penicillium rolfsii c3-2(1) IBRL. BioResources. 2015;10:1627-1643.

27. Lafond $M$, Tauzin $A$, Desseaux $V$, Bonnin E, Ajandouz EH, Giardina T. GH10 xylanase D from Penicillium funiculosum: biochemical studies and xylooligosaccharide production. Microb Cell Fact. 2011; 10:20.

Available:https://doi.org/10.1186/14752859-10-20

28. Cai $H$, Shi $P$, Bai $Y$, Huang $H$, Yuan $T$, Yang $\mathrm{P}$, Luo $\mathrm{H}$, Meng $\mathrm{K}$, Yao B. A novel thermoacidophilic family 10 xylanase from Penicillium pinophilum C1. Process Biochem. 2011;46:2341-2346.

Available:https://doi.org/10.1016/j.procbio. 2011.09.018

29. Hou $\mathrm{YH}$, Wang $\mathrm{TH}$, Long $\mathrm{H}$, Zhu HY. Novel Cold-adaptive Penicillium Strain FS010 Secreting Thermo-labile Xylanase Isolated from Yellow Sea. Acta Biochim Biophys Sin (Shanghai). 2006;38:142-149.

Available:https://doi.org/10.1111/j.17457270.2006.00135.x

30. Driss D, Driss Z, Chaari F, Chaabouni SE. Immobilization of His-tagged recombinant xylanase from Penicillium occitanis on Nickel-chelate Eupergit $C$ for increasing digestibility of poultry feed. Bioengineered. 2014;5:274-279.
Available:https://doi.org/10.4161/bioe.2959 6

31. Terrasan CRF, Guisan JM, Carmona EC. Xylanase and $\beta$-xylosidase from Penicillium janczewskii: Purification, characterization and hydrolysis of substrates. Electron J Biotechnol. 2016;23: 54-62.

Available:https://doi.org/10.1016/j.ejbt.201 6.08.001

32. Tanaka H, Nakamura $\mathrm{T}$, Hayashi $\mathrm{S}$, Ohta K. Purification and properties of an extracellular endo-1,4- $\beta$-xylanase from Penicillium citrinum and characterization of the encoding gene. J Biosci Bioeng. 2005; 100:623-630

Available:https://doi.org/10.1263/jbb.100.6 23

33. Belancic A, Scarpa J, Peirano A, et al. Biotdnolog Purification and properties of two of the enzymes. J Biotechnol. 1995;41: 71-79.

34. Bajaj BK, Sharma M, Sharma S. Alkalistable endo- $\beta-1,4-x y l a n a s e$ production from a newly isolated alkalitolerant Penicillium sp. SS1 using agro-residues. 3 Biotech. 2011;1:83-90. Available:https://doi.org/10.1007/s13205011-0009-5

35. Dutta T, Sengupta R, Sahoo R, et al. A novel cellulase free alkaliphilic xylanase from alkali tolerant Penicillium citrinum: Production, purification and characterization. Lett Appl Microbiol. 2007; 44:206-211.

DOI: 10.1111/j.1472-765X.2006.02042.x

36. Törrönen A, Rouvinen J. Structural and functional properties of low molecular weight endo-1,4- $\beta$-xylanases. J Biotechnol. 1997;57:137-149.

Available:https://doi.org/10.1016/S01681656(97)00095-3

37. Wang J, Mai G, Liu G, Yu S. Molecular cloning and heterologous expression of an acid-stable endoxylanase gene from Penicillium oxalicum in Trichoderma reesei. J Microbiol Biotechnol. 2013;23: 251-9.

Available:https://doi.org/10.4014/jmb.1208. 08030

38. Wakiyama M, Tanaka H, Yoshihara K, Hayashi S, Ohta K. Purification and properties of family-10 endo-1,4- $\beta$ xylanase from Penicillium citrinum and structural organization of encoding gene. $\mathrm{J}$ Biosci Bioeng. 2008;105:367-374. 
Available:https://doi.org/10.1263/jbb.105.3 67

39. Fedorova TV, Chulkin AM, Vavilova EA, et al. Purification, biochemical characterization, and structure of recombinant endo-1,4- $\beta$-xylanase XylE. Biochem 2012;77:1190-1198.

DOI: $10.1134 /$ S0006297912100112

40. Querido ALS, Coelho JLC, Araújo EF, Alves VMC. Partial purification and characterization of xylanase produced by Penicillium expansum. Brazilian Arch Biol Technol 2006; 49:475-480.

Available:https://doi.org/10.1590/S151689132006000400016

41. Carmona EC, Fialho MB, Buchgnani EB, Coelho GD, Brocheto-Braga MR, Jorge JA. Production, purification and characterization of a minor form of xylanase from Aspergillus versicolor. Process Biochem. 2005;40:359-364

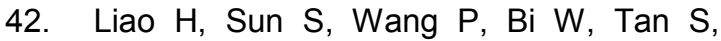
Wei Z, Mei X, Liu D, Raza W, Shen $Q$, $\mathrm{Xu} Y$. A new acidophilic endo- $\beta-1,4-$ xylanase from Penicillium oxalicum:
Cloning, purification, and insights into the influence of metal ions on xylanase activity. J Ind Microbiol Biotechnol. 2014; 41:1071-1083.

Available:https://doi.org/10.1007/s10295014-1453-0

43. Knob A, Carmona EC Purification and characterization of two extracellular xylanases from Penicillium sclerotiorum: a novel acidophilic xylanase. Appl Biochem Biotechnol.2010; 162:429-43.

Available:https://doi.org/10.1007/s12010009-8731-8

44. Lin C, Shen Z, Zhu T, Qin W. Newly Isolated Penicillium ramulosum N1 is excellent for producing protease-resistant acidophilic xylanase. J Mol Microbiol Biotechnol. 2015;25:320-326.

DOI: $10.1159 / 000439170$

45. Liu W, Shi P, Chen Q, et al. Gene cloning, overexpression, and characterization of a xylanase from Penicillium sp. CGMCC 1669. Appl Biochem Biotechnol. 2010;162: $1-12$.

DOI: $10.1007 / \mathrm{s} 12010-009-8719-4$

(c) 2020 Bittencourt et al.; This is an Open Access article distributed under the terms of the Creative Commons Attribution License (http://creativecommons.org/licenses/by/4.0), which permits unrestricted use, distribution, and reproduction in any medium, provided the original work is properly cited.

Peer-review history:

The peer review history for this paper can be accessed here: http://www.sdiarticle4.com/review-history/59171 